\title{
SEM and TEM evidence of mixed-layer illite-smectite formed by dissolution- crystallization processes in continental Paleogene sequences in northwestern Argentina
}

\author{
MARGARITA DO CAMPO ${ }^{1,}{ }^{*}$, BLANCA BAULUZ $^{2}$, FERNANDO NIETO $^{3}$, \\ CECILIA DEL PAPA ${ }^{4}$ AND FERNANDO HONGN 5 \\ ${ }^{1}$ INGEIS (CONICET - Universidad de Buenos Aires) y FCEyN - U.B.A. Pabellón INGEIS, Ciudad Universitaria \\ (1428) Buenos Aires, Argentina \\ ${ }^{2}$ Departamento de Ciencias de la Tierra, Universidad de Zaragoza, Pedro Cerbuna 12, 50.009 Zaragoza, Spain \\ ${ }^{3}$ Departamento de Mineralogía y Petrología and I.A.C.T., Universidad de Granada-CSIC, Avda. Fuentenueva s/n, \\ 18002-Granada, Spain \\ ${ }^{4}$ CICTERRA, CONICET-Universidad Nacional de Córdoba, Córdoba, Argentina \\ ${ }^{5}$ IBIGEO (CONICET-Universidad Nacional de Salta), Avda. Bolivia 5150, 4400 Salta, Argentina
}

(Received 3 March 2016; revised 19 July 2016; Associate Editor: Juan Cornejo)

\begin{abstract}
In the northernmost Calchaquí Valley (Salta, Argentina), the Paleogene continental sediments show a transition from smectite, at the top, to R3 I-S (>90\% illite) through R1 I-S (65-80\% illite), in contrast to the remaining sectors, containing smectite up to the bottom. Samples at the base of the succession were characterized by high-quality step-scan X-ray diffraction (XRD), scanning electron microscopy (SEM) and analytical high-resolution transmission electron microscopy (HRTEM). Analysis by SEM demonstrated dissolution of primary phases (feldspars, micas and quartz) and crystallization of illite, I-S and kaolinite. As this alteration is not pervasive, an intermediate fluid/rock ratio could be inferred. The lattice-fringe images of the samples from upper parts of the sequence show abundant I1-rich areas, whereas in the lower parts of the sequence, illite packets and I3 I-S coexist and compositions evolve towards muscovite (tetrahedral-charge increase, principally compensated by $\mathrm{Mg}$ by-Al substitution in octahedral sites and by a slight decrease in $\mathrm{Ca}$ in interlayer sites). As burial temperatures were probably similar in all the samples, depth was not responsible for the illite formation at the bottom. The TEM textures suggest that illitization proceeded mainly by dissolution-crystallization. The active faults close to the northern Calchaquí Valley probably promoted the circulation of hot, deep fluids, favouring illitization.
\end{abstract}

KeYwords: illite-smectite, Paleogene, Argentina, SEM, TEM, dissolution-crystallization.

The transformation from smectite to illite through mixed-layer illite-smectite (I-S) is one of the main

*E-mail: Docampo@ingeis.uba.ar https://doi.org/10.1180/claymin.2016.051.5.03 mineral reactions during the burial diagenesis of siliciclastic sediments. Since the pioneering work of Hower et al. (1976), the conditions and mechanisms involved in the transformation have been the subject of extensive work in many basins worldwide (e.g. Altaner et al., 1984; Ahn \& Peacor, 1989; Jiang et al., 1990; 
Veblen et al., 1990; Dong \& Peacor, 1996; Nieto et al., 1996; Altaner \& Ylagan, 1997; Dong et al., 1997; Bauluz et al., 2000; Abad et al., 2004; Cuadros, 2006) and has also been reproduced in laboratory experiments (Whitney \& Northrop, 1988; Huang et al., 1993). In addition, several studies have demonstrated the importance of fluid/rock ratios in this transformation (Whitney, 1990; Middleton et al., 2015).

A recent study on the evolution of Paleogene Andean foreland basins in NW Argentina, revealed enhanced diagenetic evolution in sediments cropping out in the northernmost Calchaquí Valley (Saladillo area; Figs 1, 2) (Do Campo et al., 2014). These sediments show a complete evolution from smectite at the top to R3 I-S mixed layers plus authigenic kaolinite at the bottom, through R1 I-S-type mixed layers in between, indicating the deep diagenetic transformations (Fig. 2b). The study section comprises sediments representing the infill of the Los Colorados basin (Quebrada de los Colorados Formation, QLC), recently defined as part of a broken foreland basin (del Papa et al., 2013), as well as the underlying post-rift sequences (Maíz Gordo Formation, MG, Marquillas et al., 2005).

Several indicators show that the R3 I-S formation in these Paleogene continental sediments is exceptional and not controlled by burial temperature alone. Do Campo et al. $(2010,2014)$ reported that equivalent levels of QLC in southern areas of the Los Colorados basin, including a control point located as near as $15 \mathrm{~km}$, contain smectite and no mixed-layer I-S in the basal fine-grained levels. Thus, according to the clay mineralogy, Paleogene sequences were affected by shallow diagenesis only in most parts of the Los Colorados basin, in agreement with the burial depths of $\sim 3000 \mathrm{~m}$ estimated for the sediment column and the low geothermal gradient characteristic of foreland basins (Dorsey et al., 1988; Allen \& Allen, 2005). Furthermore, shallow diagenetic conditions were also reported for the underlying sediments of the Maíz Gordo Formation in several localities (Do Campo et al., 2007).

The aim of the present paper was to understand the role of fluids and the transformation mechanisms involved in smectite illitization in the Paleogene continental sediments cropping out in the northernmost Calchaquí Valley, employing high-quality stepscan XRD, SEM and HRTEM techniques. The use of analytical and high-resolution techniques combined with deconvoluted XRD traces can be useful in understanding the complex burial/thermal history of broken foreland basins in northwestern Argentina.

\section{GEOLOGICAL FRAMEWORK}

The Calchaquí Valley is located in the Eastern Cordillera of the southern Central Andes of Argentina. The Eastern Cordillera is a morphotectonic unit characterized by thick- and thin-skinned tectonics.

The northern Calchaquí Valley (Saladillo area) is a narrow, N-S striking depression bound by upwardsconvergent reverse faults (Calchaquí and Toro Muerto) (Marrett et al., 1994). The stratigraphy of this area comprises Neoproterozoic-lower Cambrian very lowgrade metamorphic rocks of the Puncoviscana Formation (Turner, 1960). This unit is overlain unconformably by Upper Cretaceous-Paleogene sediments corresponding to the post-rift facies infilling the extensional basin (Salta Group, Turner, 1959; Salfity \& Marquillas, 1994; Marquillas et al., 2005). An unconformity separates the Salta Group from the overlying Middle Eocene Quebrada de Los Colorados (QLC) Formation (Payogastilla Group, Díaz \& Malizzia, 1983; del Papa et al., 2004) of the Andean foreland basin. Structural and sedimentary facies analyses showed considerable evidence at Saladillo of synorogenic deposition of the Quebrada de los Colorados Formation (Hongn et al., 2007). These authors concluded that folding of the Saladillo syncline was partially coeval with deposition of the QLC Formation. Deformation events, and therefore fault activity, also took place in the Neogene and Quaternary, as recorded by the intersection of fold axes (see fig. 1 in Hongn et al., 2007) and by the Quaternary faulting controlling the eruption of the Los Gemelos and Saladillo Quaternary volcanic centres (Marrett et al., 1994; Guzmán \& Petrinovic, 2008). These structures belong to an active fault system, as demonstrated by historical earthquakes in the area, one of which destroyed the town of La Poma in 1930.

The basal levels of the study section correspond to the Maíz Gordo Formation (post-rift stage of the Salta rift), which is overlain in angular unconformity by the the QLC Formation sediments. In the Saladillo area, the QLC Formation consists of a 1400 m-thick, upwards-thickening and upwards-coarsening continental succession of claystones, siltstones, sandstones and conglomerates, representing sedimentation in fluvial-alluvial plains and alluvial fan settings (del Papa et al., 2013) (Fig. 2). Based on unconformities and abrupt changes in the sedimentary facies patterns, three main depositional sequences have been recognized at the Saladillo site: Los Colorados I, Los Colorados II and Los Colorados III (LC I, LC II, and LC III, respectively, Fig. 2) (Hongn et al., 2007; del 

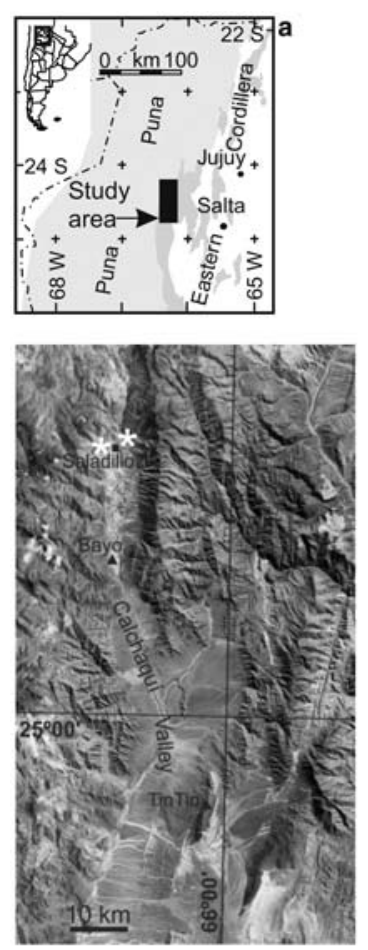

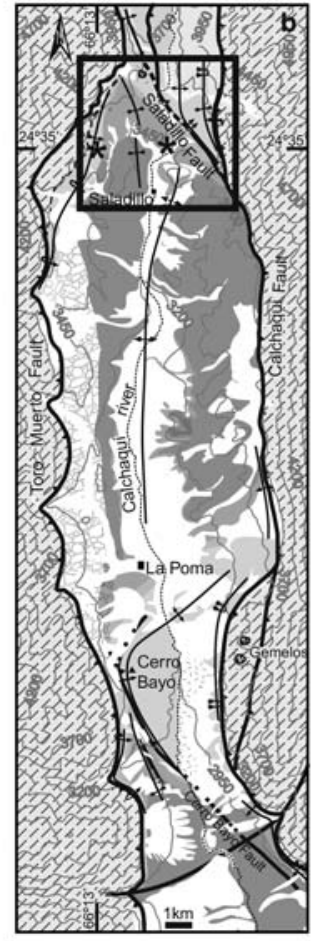

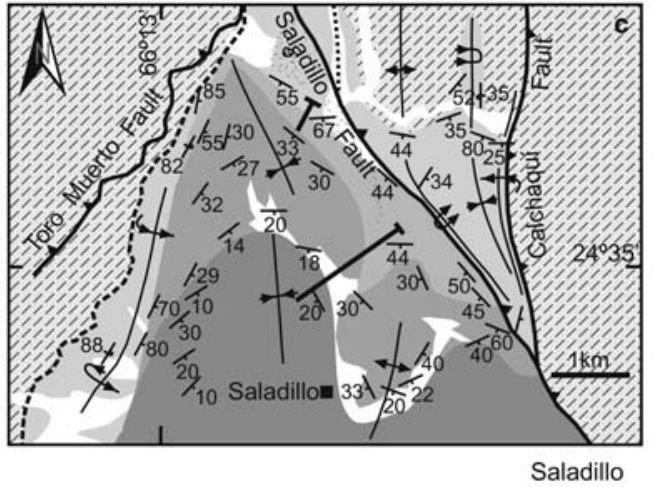

LEGEND
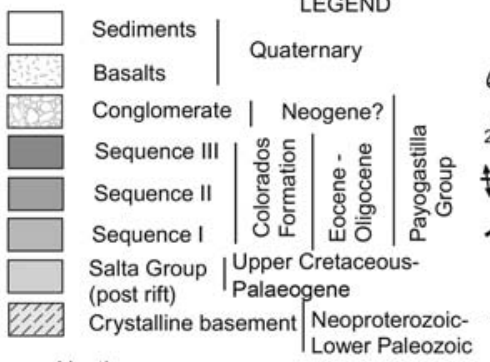

Northern

Calchaqui Valley
Modified from Hongn et al. (2007) and Do Campo et al. (2014)

FIG. 1. (a) Location and geological map of the northern Calchaquí Valley. (b) Geological map of the Saladillo area. (c) Detailed geological map of the Saladillo area and location of the stratigraphic log described in Figure 2.

Papa et al., 2013). The authigenic phases identified in the fine-grained levels of the study section (according to previous XRD and SEM data) are summarized in Fig. $2 b$ (for more details see also Do Campo et al., 2014).

\section{SAMPLING AND ANALYTICAL TECHNIQUES}

Five samples were selected from the previous study by Do Campo et al. (2014) and are described here from shallowest to deepest: sample 411-4 corresponds to a thin pelite level of the LC I sequence, located $237 \mathrm{~m}$ above the discordance between the QLC/MG formations; sample 1611-1 is from a thick pelite bed $150 \mathrm{~m}$ above the discordance between the QLC/MG formations; samples 5-7-08-4W and 5-7-08-6W correspond to pelite beds 8 and $20 \mathrm{~m}$ above the discordance, respectively; and sample 5-7-08-1 $\mathrm{W}$ is a siltstone from the MG Formation collected a few metres below the discordance separating the two units.

The five samples were studied in depth with an XRD step scan, using a PANalytical X'Pert Pro diffractometer $(\mathrm{Cu}-\mathrm{K \alpha}$ radiation, $45 \mathrm{kV}, 40 \mathrm{~mA})$ equipped with an X'Celerator solid-state linear detector, using a step increment of $0.008^{\circ} 2 \theta$ and a count time of $10 \mathrm{~s} / \mathrm{step}$ (Department of Mineralogy and Petrology, University of Granada, Spain). The XRD traces were deconvoluted using the MacDiff software (Petschick, 2004).

The textures and mineralogy of the deepest samples (5-7-08-1W, 5-7-08-4W and 5-7-08-6W) were examined by SEM on polished thin sections using backscattered electron imaging and X-ray dispersive (EDS) analysis with a ZEISS DSM 950 scanning electron microscope (SEM) (Scientific Instrument Centre, University of Granada, CIC) and Carl Zeiss MERLINTM Field Emission SEM (Servicio de Apoyo a la Investigación-Universidad de Zaragoza, Spain).

Furthermore, three samples were selected for the TEM study. Two claystones (411-4 and 1611-1) belonging to the QLC LC I sequence correspond to intermediate steps in smectite illitization and with high I-S contents, and a siltstone (5-7-08-1W) from the underlying Maíz Gordo Formation, taken a few metres below the discordance separating the two units. These samples were treated with L.R. White's resin following the procedure of Kim et al. (1995) in order to prevent the collapse of smectite-like 


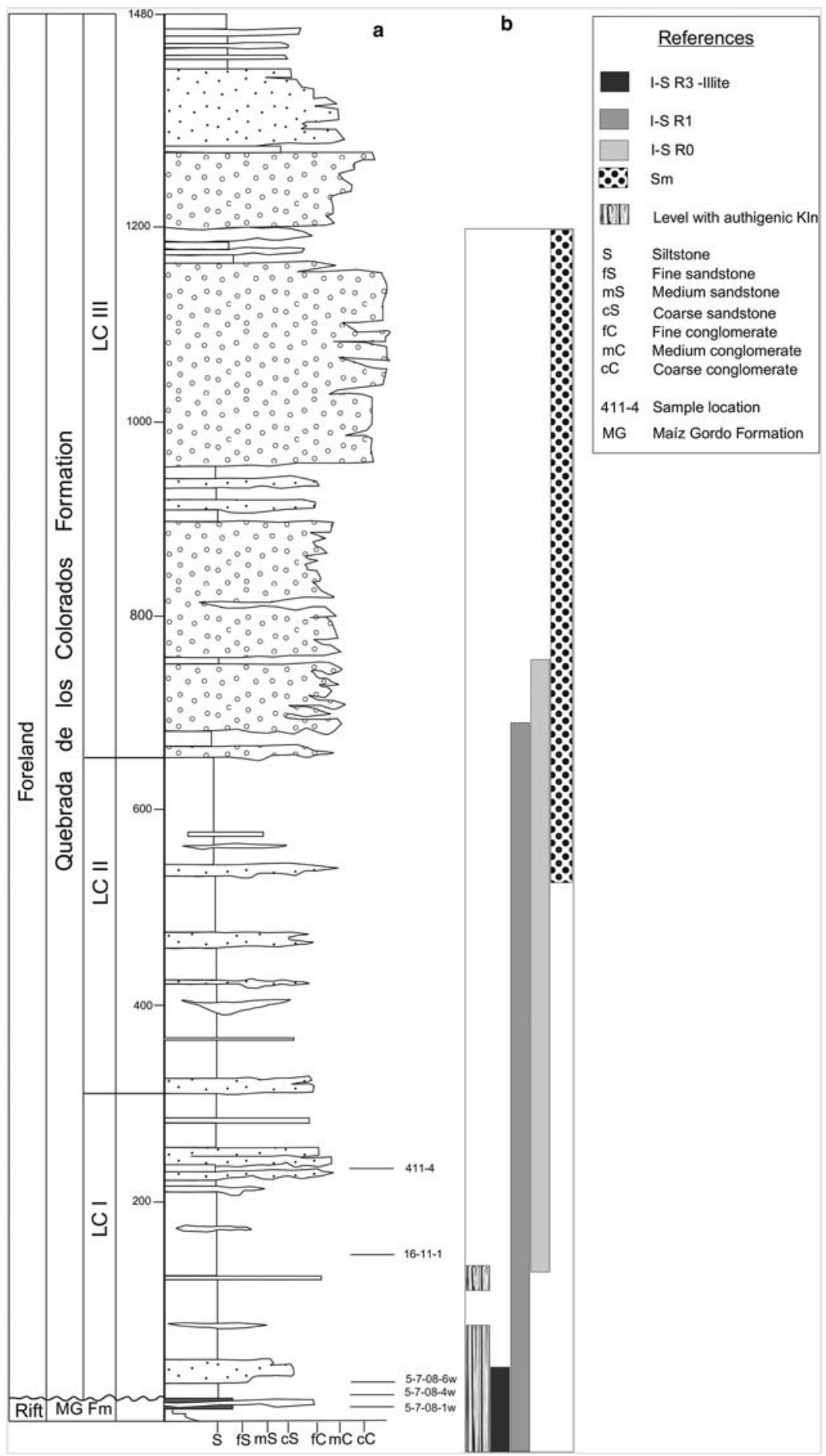

FIG. 2. (a) Simplified stratigraphic log of the Paleogene Saladillo sequences. (b). The main authigenic phases (kaolinite, smectite, R0, R1 and R3 type I-S, and, illite) in each level are indicated along the stratigraphic column. Mineralogical data from the upper part of the stratigraphic column are from the previous study by Do Campo et al. (2014). 
interlayers in the vacuum of the ion mill and TEM and thereby facilitate the differentiation of illite and smectite interlayers in TEM images. Direct contact with water during sample preparation was avoided in order to prevent smectite swelling which would result in sample damage. Sticky wax-backed thin sections were prepared with surfaces normal to bedding and first examined by optical microscopy. Typical areas were removed for TEM observation via attached $\mathrm{Cu}$ washers, thinned in an ion mill and carbon coated. The TEM data were obtained using a JEOL-2000 FXII instrument equipped with an Oxford instruments dectector (EDS) at the University of Zaragoza (Spain). The TEM was operated at $200 \mathrm{kV}$ with a beam current of $20 \mu \mathrm{A}$. Through-focus image series were obtained from $1000 \AA$ underfocus (approximate Scherzer defocus) to $1000 \AA$ overfocus, in part to obtain optimum contrast in I-S ordering (overfocus). However, because the initial focus was controlled manually by minimizing contrast, small deviations from exact underfocus or overfocus numbers were inevitable.

In order to obtain chemical analyses of individual grains with an EDAX microanalysis system, samples were studied by TEM using a Philips CM-20 operated at $200 \mathrm{kV}$ (University of Granada) on scattered powders deposited on gold-coated grids. Atomic concentration ratios were converted into formulae according to stoichiometry (oxygens in the theoretical formulae of minerals). Accordingly, the structural formulae of mixedlayer I-S were calculated on the basis of 22 negative charges. The tetrahedral sites were filled with $\mathrm{Al}$ to make $\mathrm{Si}+\mathrm{Al}=4$, and the remaining $\mathrm{Al}$ was assigned to octahedral positions. All the Fe was assumed to be ferric and all $\mathrm{Mg}$ was assigned to octahedral sites.

\section{Nomenclature for mixed-layer I-S}

Ordering in mixed-layer I-S is usually characterized by its Reichweite value on the basis of XRD data. Such measurements of I-S ordering represent long-range ordering averaged over all layers that scatter X-rays. Short-range ordering of interlayers within I-S packets can be identified in TEM images, however. The Reichweite nomenclature is therefore inappropriate for specific layer sequences as observed by TEM. The nomenclature proposed by Bauluz et al. (2000) is used herein, which utilizes the symbol $\mathrm{I} n$, where $n$ is the number of illite-like layers associated with a given smectite-like layer, i.e. layers of IS are denoted as an I1 unit, ISI as an I2 unit, and so on. This nomenclature is analogous to the Reichweite nomenclature, but is applied only to specific layers.
An ideal rectorite-type sample for which $\mathrm{R}=1$, having $50 \%$ illite-like layers, is identical to a sequence of I1 units. However, a sequence with $\mathrm{R}=1$ and $\mathrm{I} \%$ $>50 \%$ would consist mainly of I1 units, but would also have $\mathrm{I} 2, \mathrm{I} 3 \ldots$ units $(n>1)$.

\section{RESULTS \\ Clay mineralogy $-X R D$ results}

Sample 411-4 (QLC Formation) is composed of quartz, K-feldspar, plagioclase, kaolinite, mixed-layer I-S, illite-mica and scarce chlorite, with calcite cement and minor hematite. Deconvolution of the XRD trace in the region $16-17^{\circ} 2 \theta$ (Fig. 3a) revealed two peaks with 5.31 and $5.16 \AA$ indicating the presence of R1 I-S with illite contents of $\sim 65 \%$ and $85 \%$, respectively, according to Moore \& Reynolds (1997). Deconvolution of the low-angle region indicates that $\mathrm{R} 1$ is the predominant type of I-S, and shows a very weak peak at $15.57 \AA$, corresponding to minor R0 I-S.

Sample 1611-1 (QLC Formation) consists of quartz, plagioclase, illite-mica, kaolinite, mixed-layer I-S, scarce chlorite and hematite. Deconvolution of XRD traces in the region between 16 and $17^{\circ} 2 \theta$ (Fig. 3b) discriminates two peaks at 5.30 and $5.14 \AA$, corresponding to R1 I-S with illite contents of $\sim 70 \%$ and $85 \%$, respectively (Moore \& Reynolds, 1997). In contrast, deconvolution in the region between 8 and $10^{\circ} 2 \theta$ differentiates two peaks matching those identified between 16 and $17^{\circ} 2 \theta$, but also weak peaks at 9.17 and $10.68 \AA$, the former indicating subordinate R0 I-S with 55\% illite layers and the latter corresponding to minor R3-type I-S.

Sample 5-7-08-6W (QLC Formation) consists of quartz, plagioclase, K-feldspar, illite-mica, kaolinite, mixed-layer I-S and hematite. Deconvolution in the region between 8 and $10^{\circ} 2 \theta$ differentiated between I-S R3 ( $>90 \%$ illite layers) and R1 I-S. However, in the region of $16-17^{\circ} 2 \theta$, deconvolution was impossible, indicating that (002) illite and (002/003) R3 I-S reflections almost coincide.

Sample 5-7-08-4W (QLC Formation) consists of quartz, plagioclase, illite-mica, kaolinite, minor mixed-layer I-S and hematite. Deconvolution of the peaks corresponding to mixed-layer I-S was not possible due to its low abundance.

Sample 5-7-08-1W (MG Formation) consists of quartz, plagioclase, illite-mica, kaolinite, mixed-layer I-S and hematite. Deconvolution of the low-angle region of XRD traces discriminated between I-S R3 ( $>90 \%$ illite layers) and subordinate R1 I-S (Fig. 3c). As for sample 5-7-08-6W, deconvolution in the region 
of $16-17^{\circ} 2 \theta$ was not possible, indicating that $(002)$ illite and (002/003) R3 I-S reflections almost coincide.

\section{SEM results}

Backscattered electron images (BSE) of sample 5-708-6W (QLC Formation) display abundant detrital clasts of albite, Na-Ca plagioclase, K-feldspar and quartz partially dissolved and replaced by booklets of kaolinite or mixed-layer I-S (Fig. 4a-d). Textural relationships between kaolinite and mixed-layer I-S do not allow us to infer a paragenetic sequence.

Illitic phases, which, according to XRD correspond to mixed-layer I-S, are the main clay minerals in the matrix. According to the microanalyses their compositions range from smectite-rich I-S to illite-rich I-S, or even to illite, with interlayer charges ranging from 0.29 to 0.73 e.p.f.u (Table 1). Mixed-layer I-S also forms micrometre-scale intergrowths with kaolinite (Fig. 4e). Besides, both phases occur closely associated with calcite (mostly $\mathrm{Mg}$ and/or Fe-Mg bearing) or dolomite cements in the matrix. Kaolinite also occurs filling pores of the rock.

On the other hand, in the pelite 5-7-08-4W (QLC Formation), albite, Na-rich plagioclase and quartz are mainly replaced by kaolinite (Fig. 4f), in agreement with XRD data indicating the low abundance of mixedlayer I-S in this sample. In this pelite, kaolinite partly replaces detrital mica laths (Fig. 5a), frequently showing displacive precipitation along the cleavage planes (De Ros, 1998; Arostegui et al., 2001).

Sample 5-7-08-1W (MG Formation)) comprises abundant detrital clasts of quartz and mica, whereas feldspars are scarce. According to BSE and EDS the authigenic phyllosilicates identified in the matrix were illite, illite-rich I-S and kaolinite in close association (Fig. 5b,c, Table 1). Mixed layer I-S also occurs replacing irregular quartz grains (Fig. 5b). In this sample kaolinite partly replaces detrital mica laths, also showing displacive precipitation along the cleavage planes similar to the previous sample (Fig. 5c). Kaolinite also replaces plagioclase clasts (Fig. 5d, white arrow) and occurs in pores in the rock.

\section{Transmission electron microscopy (TEM)}

Sample 411-4 (QLC Formation). The phyllosilicates identified in this sample by TEM were I1 mixed-layer I-S and illite. Low-magnification TEM images show thin packets of mixed-layer I-S with curved and anastomosing morphologies depicting high-angle terminations with similar packets of contrasting orientation (Fig. 6a). The SAED patterns (Fig. 6a inset) of I-S display $00 l$ reflections corresponding to $10 \AA$ periodicity in the $00 l$ row, and ill-defined and non-periodic reflections, or even a line of streaking (diffuseness parallel to $c^{*}$ ) in rows with $\mathrm{k} \neq 0$, indicating $1 M_{d}$ polytypism. Diffuseness normal and parallel to $c^{*}$ is ubiquitous in the $00 l$ row, the former being a consequence of the changes in orientation of adjacent packets, whereas the latter originates from interlayering. Figure $6 \mathrm{~b}, \mathrm{c}$ shows two lattice-fringe images representative of mixed-layer I-S, with packets only a few layers thick ( $\sim 50-80 \AA)$, depicting the alternating dark and light contrast typical of mixedlayer I-S. Adjacent packets frequently have a slightly different orientation, with curved and discontinuous (001) fringes with spacings corresponding to the sum of illite- and smectite-like layer spacings (21-22 $\AA$ periodicity). Although deconvolution of the XRD trace discriminates peaks corresponding to R1 and minor R0 (Fig. 3a), only the dominant I1 layer sequences were identified in I-S mixed-layer packets in TEM images. Abundant lens-shaped voids are consistent with partial collapse caused by the TEM vacuum despite sample treatment with L.R. White resin. Mixed layers are oblique to subparallel to straight or slightly curved with respect to illite packets; in general, the two phases are separated by ellipsoidal or triangular regions lacking lattice fringes (Fig. 6c). Illite packets (60-120 $\AA$ thick) consist of straight lattice fringes with constant $10 \AA$ spacings, displaying uniform contrast consistent with relatively constant orientation, although they depict abundant layer terminations (Fig. 6b,c).

Sample 1611-1 (QLC Formation). Phyllosilicates identified in this sample by TEM were I1 I-S, illite and occasionally I2 and/or I3 I-S sequences, kaolinite and chlorite.

At low magnification, packets exhibit a curved and anastomosing morphology, without preferential orientation and high-angle layer terminations (Fig. 7a). Collapsed layers are abundant. Figure $7 \mathrm{a}$ depicts detrital micas $>200 \AA$ thick next to curved and anastomosing packets of mixed-layer I-S oriented oblique or even perpendicular to the former; replacement of detrital micas by authigenic I-S are also observed (Fig. 7a, white arrows). Iron oxides frequently occur in close association with authigenic I-S (Fig. 7a). The SAED patterns with very diffuse 10 $10.4 \AA(001)$ reflections elongated normal to $c^{*}$ as a result of the curvature of I-S layers were obtained, indicating that I-S collapsed under the vacuum of the ion mill and TEM (Fig. 7a, inset). Less frequently, SAED patterns displaying $00 l$ reflections 
a

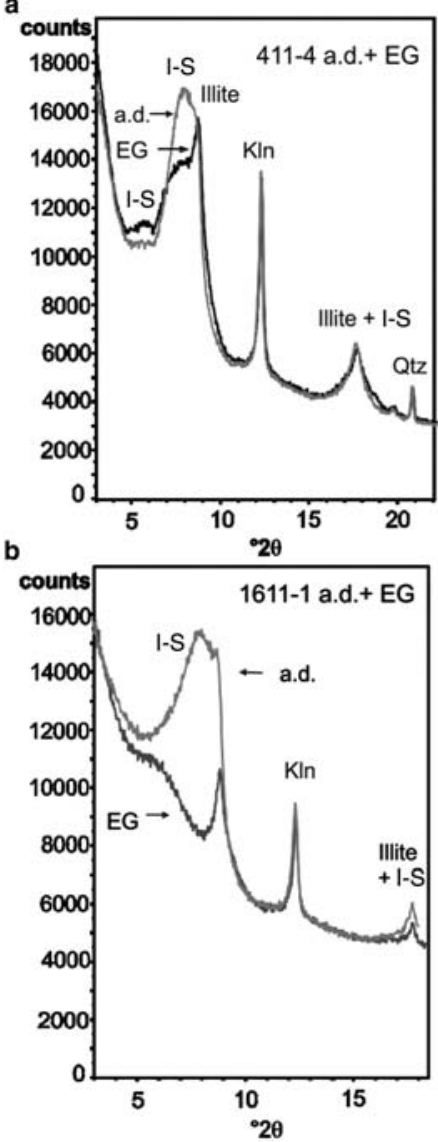

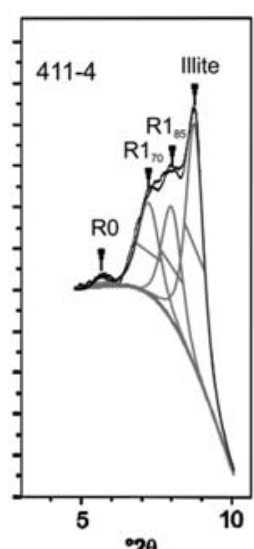

${ }^{\circ} 2 \theta$

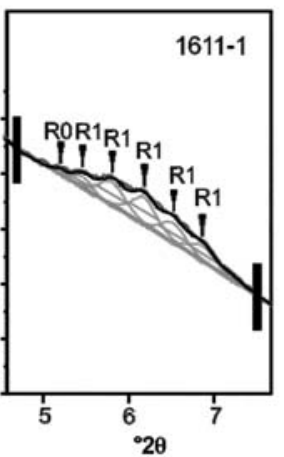

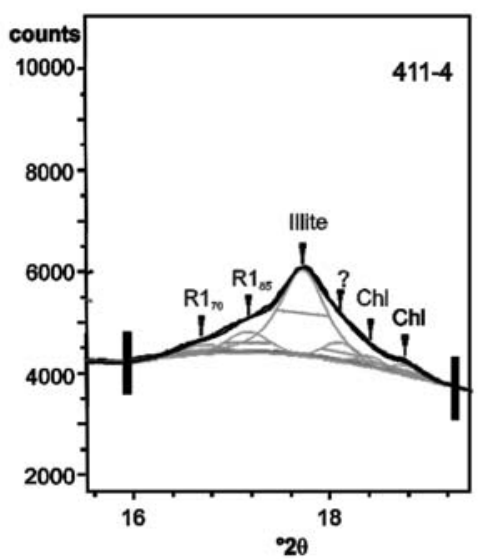
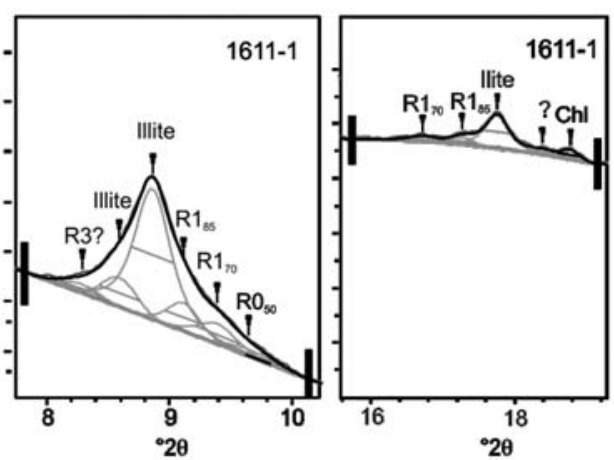

c
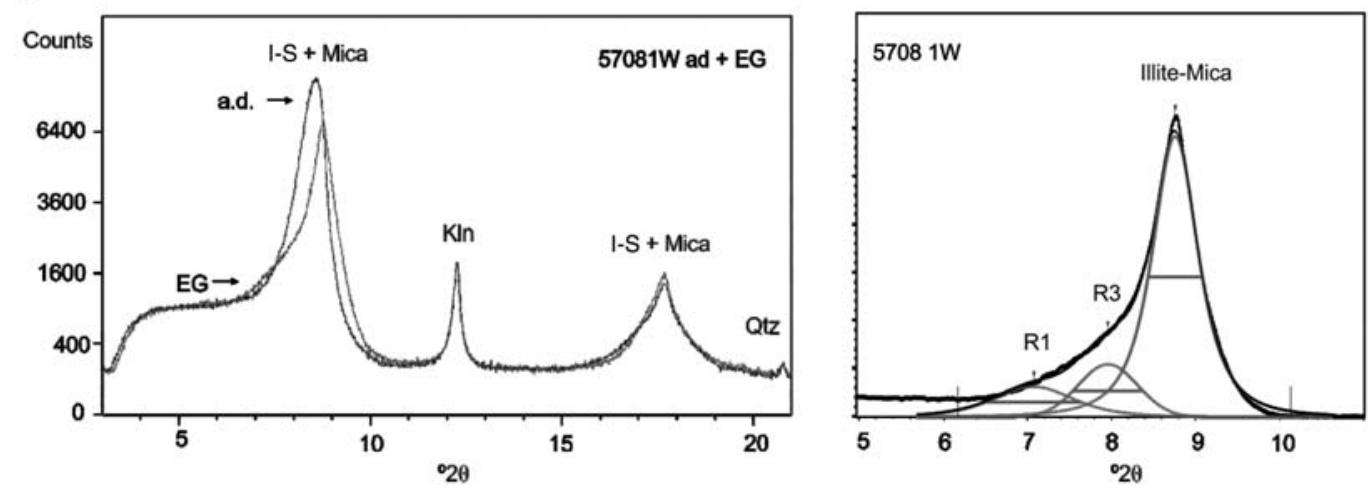

FIG. 3. The left-hand column shows air-dried and ethylene glycol-solvated XRD patterns of $<2 \mathrm{~m}$ sub-samples for the three samples studied by TEM: (a) QLC, middle LCI sequence, sample 411-4; (b) QLC, middle LCI, sample 1611-1; (c): Maíz Gordo Formation sample 5-7-08-1W. The right-hand columns show decomposition of the lowangle region of the XRD patterns (obtained using MacDiff). The percentages of illite layers in R0 and R1 I-S are indicated as subscripted numbers in parts a and b, according to Moore and Reynolds (1997). See the text for peak positions. 


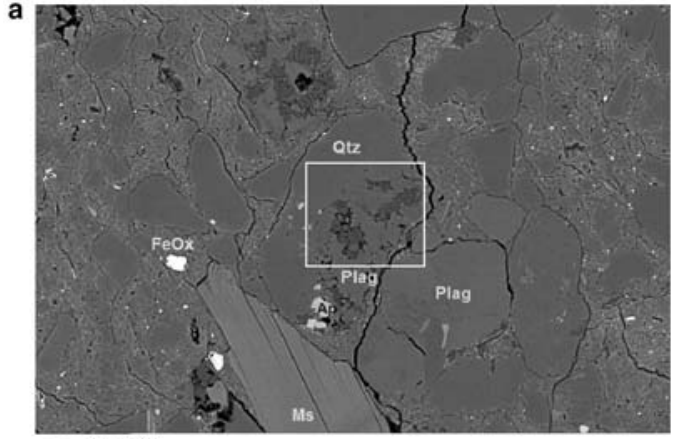

$\mapsto 10 \mu \mathrm{m}$

\section{c}

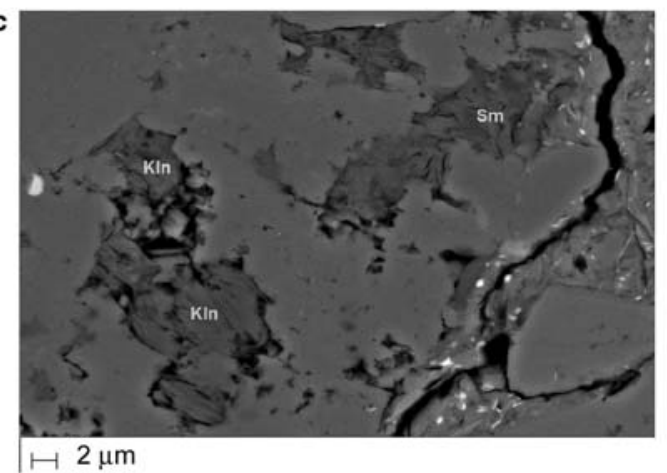

e

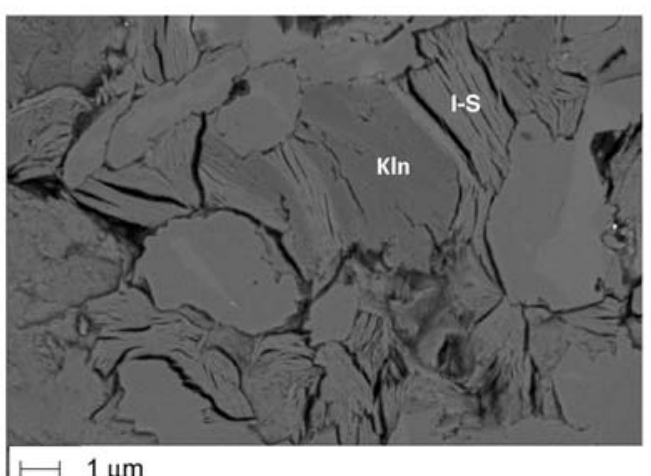

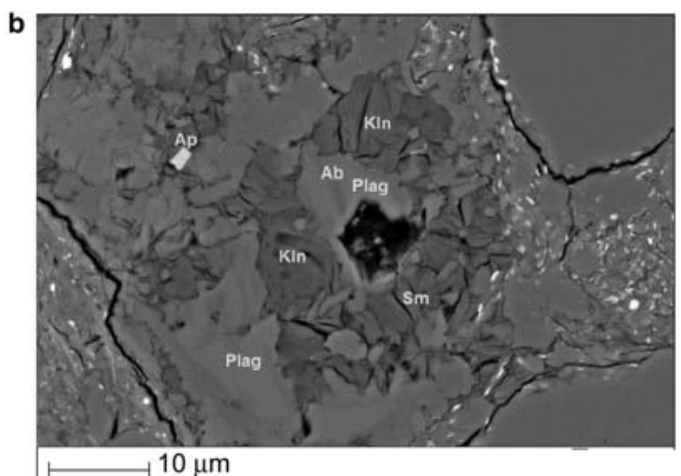

d

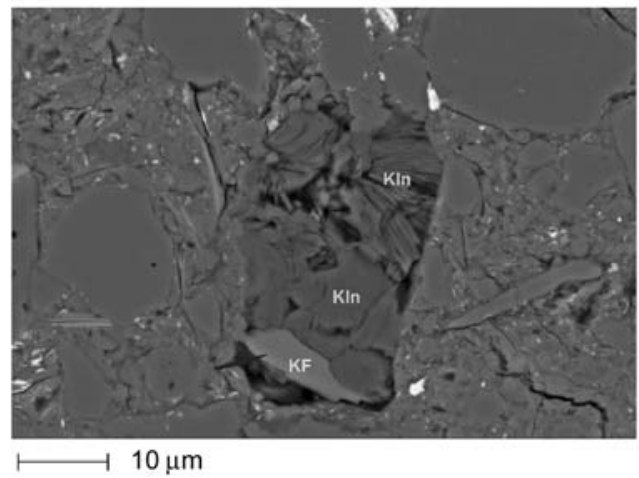

f

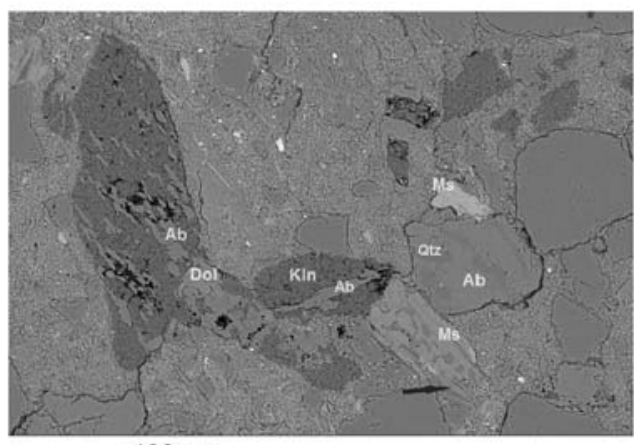

$100 \mu \mathrm{m}$

FIG. 4. (a) BSE images (a-e): sample 5-7-08-6W. (a) Clasts of quartz and Na-rich plagioclase partially dissolved and replaced by kaolinite and mixed-layer I-S. (b) Enlargement of part a: kaolinite and mixed-layer I-S replacing a clast of plagioclase. (c) Enlargement of boxed area in part a: clast of quartz partially dissolved and replaced by kaolinite and mixed-layer I-S. (d) Remnant of a K-feldspar clast surrounded by booklets of kaolinite. (e) Enlargement of part b showing intergrowths of kaolinite and mixed-layer I-S at micrometre scale. (f) Sample 5-7-08-4W. Clasts of albite heavily dissolved and replaced by kaolinite; grain of dolomite replaced by kaolinite, and laths of detrital mica showing replacement by kaolinite.

corresponding to $10 \AA$ periodicity in the $00 l$ row and ill-defined and non-periodic reflections and diffuseness parallel to $c^{*}$ in rows with $\mathrm{k} \neq 3 \mathrm{n}$ (indicating $1 M_{d}$ polytypism) were obtained for mixed-layer I-S. Lattice fringes have a wavy appearance (Fig. $7 \mathrm{~b}$ ) and the alternating dark and light contrast typical of mixedlayer I-S. An along-layer transition from 15.2 to $10.2 \AA$ was observed (Fig. 7c, black arrow). Layer sequences corresponding to I1 and occasionally to I2 and/or I3 were identified in mixed-layer I-S, although I1 is the most 
TABLE 1. Representative structural formulae for I-S according to AEM data.

\begin{tabular}{|c|c|c|c|c|c|c|c|c|}
\hline & \multicolumn{8}{|c|}{$411-4$} \\
\hline & $11-1$ & $11-2$ & $11-6$ & $11-7$ & $11-8$ & $11-9$ & $11-13$ & \\
\hline $\mathrm{Si}$ & 3.44 & 3.40 & 3.50 & 3.56 & 3.62 & 3.40 & 3.43 & \\
\hline${ }^{\mathrm{IV}} \mathrm{Al}$ & 0.56 & 0.60 & 0.50 & 0.44 & 0.38 & 0.60 & 0.57 & \\
\hline${ }^{\mathrm{VI}} \mathrm{Al}$ & 1.52 & 1.53 & 1.63 & 1.44 & 1.62 & 1.63 & 1.66 & \\
\hline $\mathrm{Fe}$ & 0.25 & 0.25 & 0.23 & 0.33 & 0.21 & 0.21 & 0.21 & \\
\hline $\mathrm{Mg}$ & 0.34 & 0.33 & 0.24 & 0.28 & 0.28 & 0.23 & 0.26 & \\
\hline $\mathrm{Mn}$ & 0.00 & 0.00 & 0.00 & 0.00 & 0.00 & 0.00 & 0.02 & \\
\hline $\mathrm{Ti}$ & 0.00 & 0.00 & 0.02 & 0.00 & 0.00 & 0.02 & 0.00 & \\
\hline Eoct. & 2.10 & 2.11 & 2.12 & 2.05 & 2.11 & 2.08 & 2.15 & \\
\hline$\overline{\mathrm{K}}$ & 0.44 & 0.47 & 0.23 & 0.47 & 0.23 & 0.46 & 0.26 & \\
\hline $\mathrm{Na}$ & 0.00 & 0.00 & 0.00 & 0.00 & 0.00 & 0.00 & 0.00 & \\
\hline $\mathrm{Ca}$ & 0.07 & 0.07 & 0.07 & 0.05 & 0.05 & 0.05 & 0.07 & \\
\hline \multirow[t]{3}{*}{ Int $_{\text {charge }}$} & 0.58 & 0.61 & 0.37 & 0.58 & 0.33 & 0.56 & 0.40 & \\
\hline & \multicolumn{8}{|c|}{$1611-1$} \\
\hline & $11-1$ & $11-2$ & $11-3$ & $11-4$ & $11-5$ & $11-7$ & $11-8$ & $11-9$ \\
\hline $\mathrm{Si}$ & 3.46 & 3.43 & 3.29 & 3.40 & 3.47 & 3.59 & 3.32 & 3.57 \\
\hline${ }^{\mathrm{IV}} \mathrm{Al}$ & 0.54 & 0.57 & 0.71 & 0.60 & 0.53 & 0.41 & 0.68 & 0.43 \\
\hline${ }^{\mathrm{VI}} \mathrm{Al}$ & 1.42 & 1.42 & 1.56 & 1.42 & 1.47 & 1.59 & 1.57 & 1.44 \\
\hline $\mathrm{Fe}$ & 0.28 & 0.27 & 0.25 & 0.25 & 0.28 & 0.17 & 0.23 & 0.23 \\
\hline $\mathrm{Mg}$ & 0.39 & 0.35 & 0.32 & 0.43 & 0.30 & 0.24 & 0.23 & 0.37 \\
\hline $\mathrm{Mn}$ & 0.00 & 0.00 & 0.00 & 0.00 & 0.00 & 0.00 & 0.00 & 0.00 \\
\hline $\mathrm{Ti}$ & 0.00 & 0.02 & 0.02 & 0.02 & 0.00 & 0.02 & 0.02 & 0.00 \\
\hline Eoct. & 2.10 & 2.06 & 2.14 & 2.12 & 2.05 & 2.02 & 2.05 & 2.03 \\
\hline $\mathrm{K}$ & 0.42 & 0.51 & 0.44 & 0.48 & 0.49 & 0.37 & 0.60 & 0.10 \\
\hline $\mathrm{Na}$ & 0.00 & 0.00 & 0.00 & 0.00 & 0.00 & 0.00 & 0.00 & 0.00 \\
\hline $\mathrm{Ca}$ & 0.11 & 0.11 & 0.07 & 0.09 & 0.09 & 0.10 & 0.07 & 0.30 \\
\hline \multirow[t]{3}{*}{ Int $_{\text {charge }}$} & 0.64 & 0.72 & 0.58 & 0.66 & 0.67 & 0.58 & 0.74 & 0.70 \\
\hline & \multicolumn{5}{|c|}{$1611-1$} & \multicolumn{2}{|c|}{$5-7-08-1 \mathrm{~W}$} & \\
\hline & $11-10$ & $11-12$ & $11-13$ & $11-14$ & $11-15$ & $11-1$ & $11-6$ & \\
\hline $\mathrm{Si}$ & 3.79 & 3.79 & 3.56 & 3.77 & 3.53 & 3.40 & 3.31 & \\
\hline${ }^{\mathrm{IV}} \mathrm{Al}$ & 0.21 & 0.21 & 0.44 & 0.23 & 0.47 & 0.60 & 0.69 & \\
\hline${ }^{\mathrm{VI}} \mathrm{Al}$ & 1.49 & 1.59 & 1.56 & 1.52 & 1.58 & 1.54 & 1.57 & \\
\hline $\mathrm{Fe}$ & 0.23 & 0.21 & 0.28 & 0.24 & 0.21 & 0.35 & 0.32 & \\
\hline $\mathrm{Mg}$ & 0.23 & 0.22 & 0.24 & 0.28 & 0.21 & 0.21 & 0.21 & \\
\hline $\mathrm{Mn}$ & 0.00 & 0.00 & 0.00 & 0.00 & 0.00 & 0.00 & 0.00 & \\
\hline $\mathrm{Ti}$ & 0.00 & 0.02 & 0.00 & 0.00 & 0.02 & 0.05 & 0.02 & \\
\hline Eoct. & 1.94 & 2.04 & 2.09 & 2.03 & 2.02 & 2.15 & 2.12 & \\
\hline $\mathrm{K}$ & 0.19 & 0.09 & 0.25 & 0.16 & 0.47 & 0.26 & 0.53 & \\
\hline $\mathrm{Na}$ & 0.00 & 0.00 & 0.00 & 0.00 & 0.00 & 0.00 & 0.00 & \\
\hline $\mathrm{Ca}$ & 0.21 & 0.10 & 0.09 & 0.12 & 0.07 & 0.02 & 0.00 & \\
\hline Int $_{\text {charge }}$ & 0.61 & 0.29 & 0.42 & 0.41 & 0.61 & 0.30 & 0.53 & \\
\hline
\end{tabular}

Analyses were normalized for $10 \mathrm{O}$ and $2(\mathrm{OH})$.

common ordering type (Fig. 7c), in agreement with XRD data (Fig. 3b). Illite packets (30-200 $\AA$ thick) are straight to slightly curved, depicting homogeneous contrast along and across layers (Fig. 7c). The white arrow indicates a low-angle boundary between illite and mixed-layer I-S packets, with abundant layer terminations. 

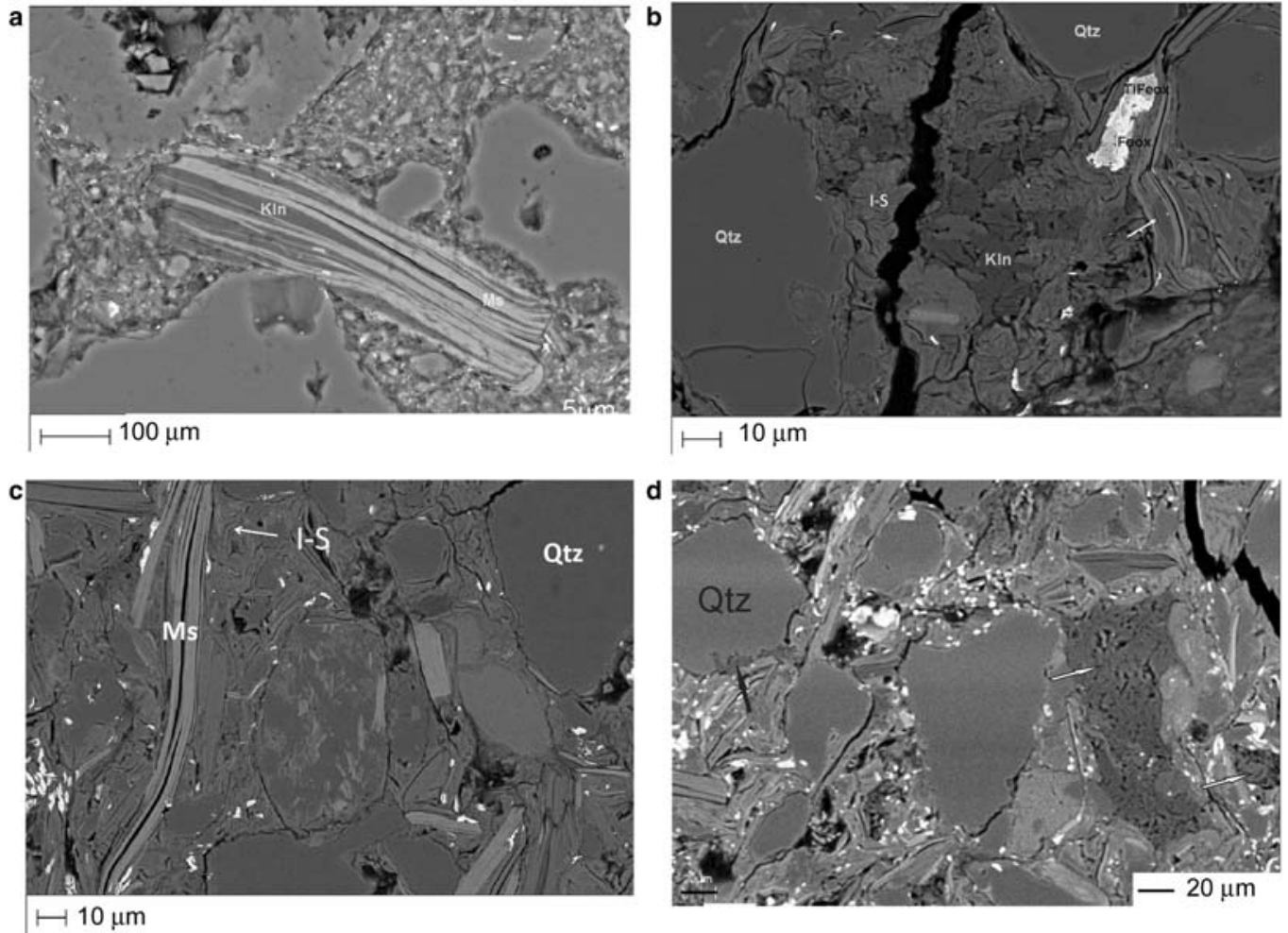

FIG. 5. (a) Enlargement of Fig. 4f: laths of detrital mica showing pseudomorphic replacement of the lamellae and additional displacive kaolinite precipitation between the cleavage planes (sample 5-7-08-4W). (b-d) Sample 5-7-08-1 W Maíz Gordo Formation. (b) Booklets of kaolinite and bunches of mixed-layer I-S in the matrix and laths of detrital mica showing pseudomorphic replacement of the lamellae (white arrow). (c) Bunches of mixed-layer I-S in the matrix, and kaolinite replacing detrital mica grains. (d) Clast of quartz (black arrow) and albite partially replaced by kaolinite (white arrow).

Sample 5-7-08-1W (MG Formation). In this sample, illite, I1 and I3 mixed-layer I-S occur in adjacent packets with low-angle boundaries between them in illite-rich areas (Fig. 8a,b), in agreement with the XRD data that indicate R1 and R3 (Fig. 3c). Illite forms subparallel packets $(60-240 \AA$ thick), with straight and relatively defect-free lattice (001) fringes with lowangle boundaries (Fig. 8b, white arrow). The SAED patterns of illite crystals indicate $1 M_{d}$ polytypism (Fig. 8c).

In contrast, in mixed-layer I-S-rich areas, packets of I-S (60-200 § thick) and illite (no preferred orientation) with high-angle boundaries between them predominate (Fig. 9). In such areas, layer sequences corresponding to I1, I3 and I > 3 I-S were singled out; furthermore, along-layer transitions between I-S and illite were identified (Fig. 9).

\section{Analytical electron microscopy (AEM)}

Structural formulae calculated from new data for mixed-layer I-S are shown in Table 1. Figure 10 also includes data from the previous study by Do Campo et al. (2014). The usual Si/Al ratio change with depth (Fig. 10a) in tetrahedral layers is clearly present in the samples examined here.

The chemical compositions of mixed-layer I-S of samples 411-4 and 1611-1 (intermediate steps in smectite illitization, shallower samples) are similar; they depict large compositional variations and overlap each other in the compositional diagrams (Fig. 10). This is consistent with the XRD and TEM data because they are formed by at least two types of dioctahedral clays. In contrast, mixed-layer I-S of sample 5-7-8-1W (evolved step in smectite illitization, deepest sample) show more 

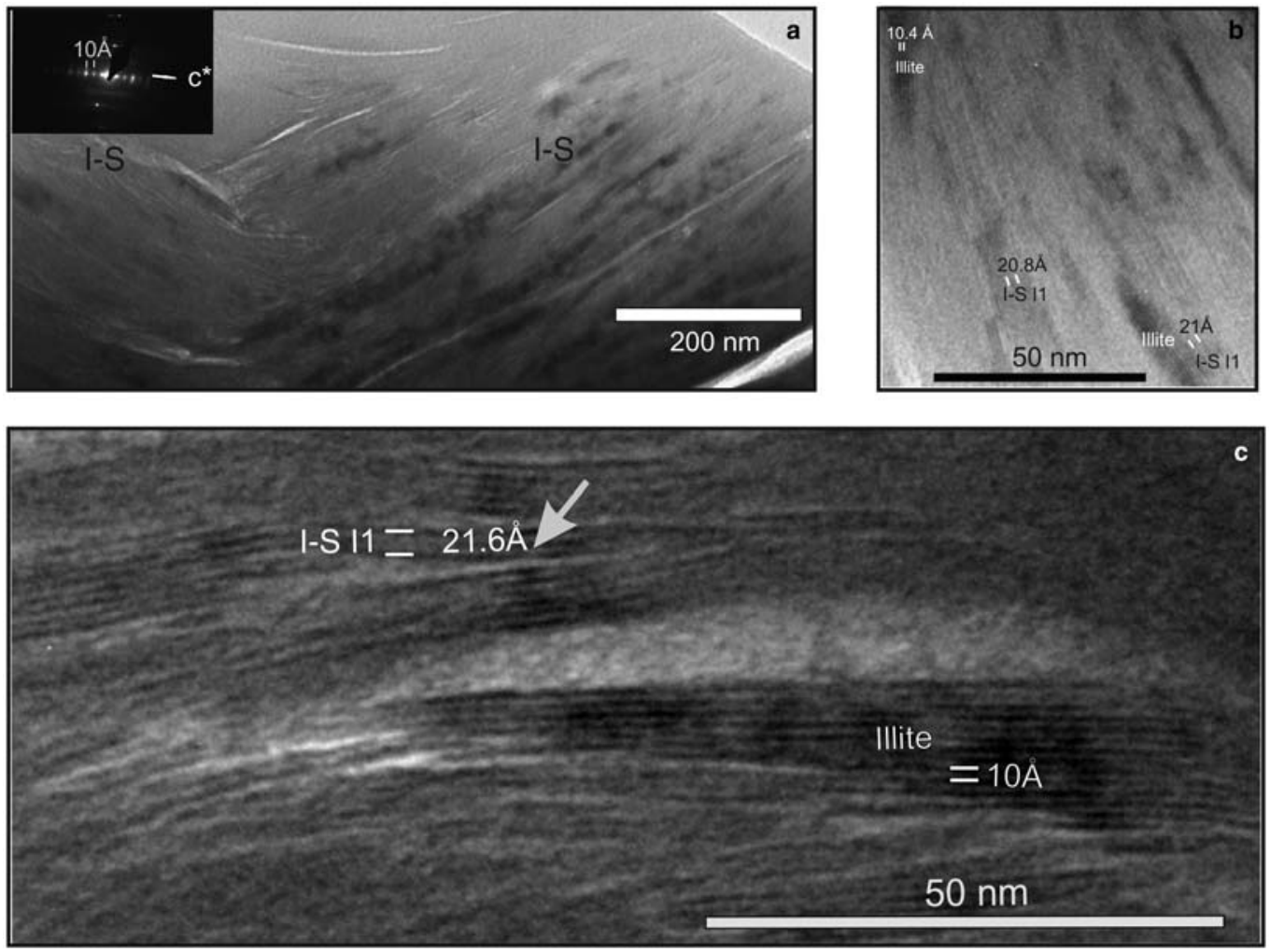

FIG. 6. TEM images of sample 411-4. (a) Low-magnification TEM image and SAED pattern showing thin packets of mixed-layer I-S with curved and anastomosing morphologies oriented at high angles to one another. $(b, c)$ Lattice-fringe images showing thin packets of mixed-layer I-S ( 50-80 ̊) with curved and discontinuous (001) fringes with spacings corresponding to the sum of illite- and smectite-like layer spacings (21-22 A periodicity), indicating I1 ordering type. Adjacent packets frequently show a slightly different orientation (b, centre). Lens-shaped voids consistent with partial collapse caused by the TEM vacuum despite sample treatment with L.R. White resin can be seen (c).

homogeneous compositions (Fig. 10). The most significant differences among dioctahedral clays in these samples are the lower $\mathrm{Ca}$ and $\mathrm{Mg}$ contents in $\mathrm{I}-\mathrm{S}$ in the deepest sample (Fig. 10b,c) and the increase in the $\mathrm{K}$ and Al contents (Fig. 10a,d) from shallower to deepest samples, reflecting an increase in the illitization process. Accordingly, Si-K, Si-Mg and Si-Al compositional diagrams (Fig. 10a,c,d) reveal three groups of analysis: group 1 probably corresponds to smectite or R0 I-S compositions, group 2 corresponds to R1 I-S compositions, and group 3 to illite (or R3 I-S) analysis.

\section{DISCUSSION}

\section{XRD vs. TEM results}

The XRD data show that the samples analysed consist of complex mixtures of mixed-layer I-S with different Reichweite orders. In summary, samples 4114 and 1611-1 are mainly composed of R1 mixed-layer I-S with $65-80 \%$ illite layers. R1 coexists with very scarce R0 in both samples, whereas minor R3 I-S might be present in sample 1611-1. In contrast, sample $5-7-08-1 \mathrm{~W}$ consists mainly of R3 I-S $(>90 \%$ illite layers) and minor R1 I-S. Thus, XRD shows a significant change from the two shallowest to the deepest samples $(5-7-08-1 \mathrm{~W})$, in which there is an apparent increase in diagenetic grade.

The TEM images confirm that I1 is the most abundant dioctahedral clay in samples 411-4 and 1611-1, coexisting with discrete illite. Furthermore, in sample 1611-1, this I-S occasionally coexists with I-S having I $>1$. In contrast, based on the TEM study, sample 5-7-08-1W consists of illite and I1 I-S, with minor I > 1 I-S.

Both techniques show good agreement in the identification of R1 I-S, and the R3 I-S with a large 

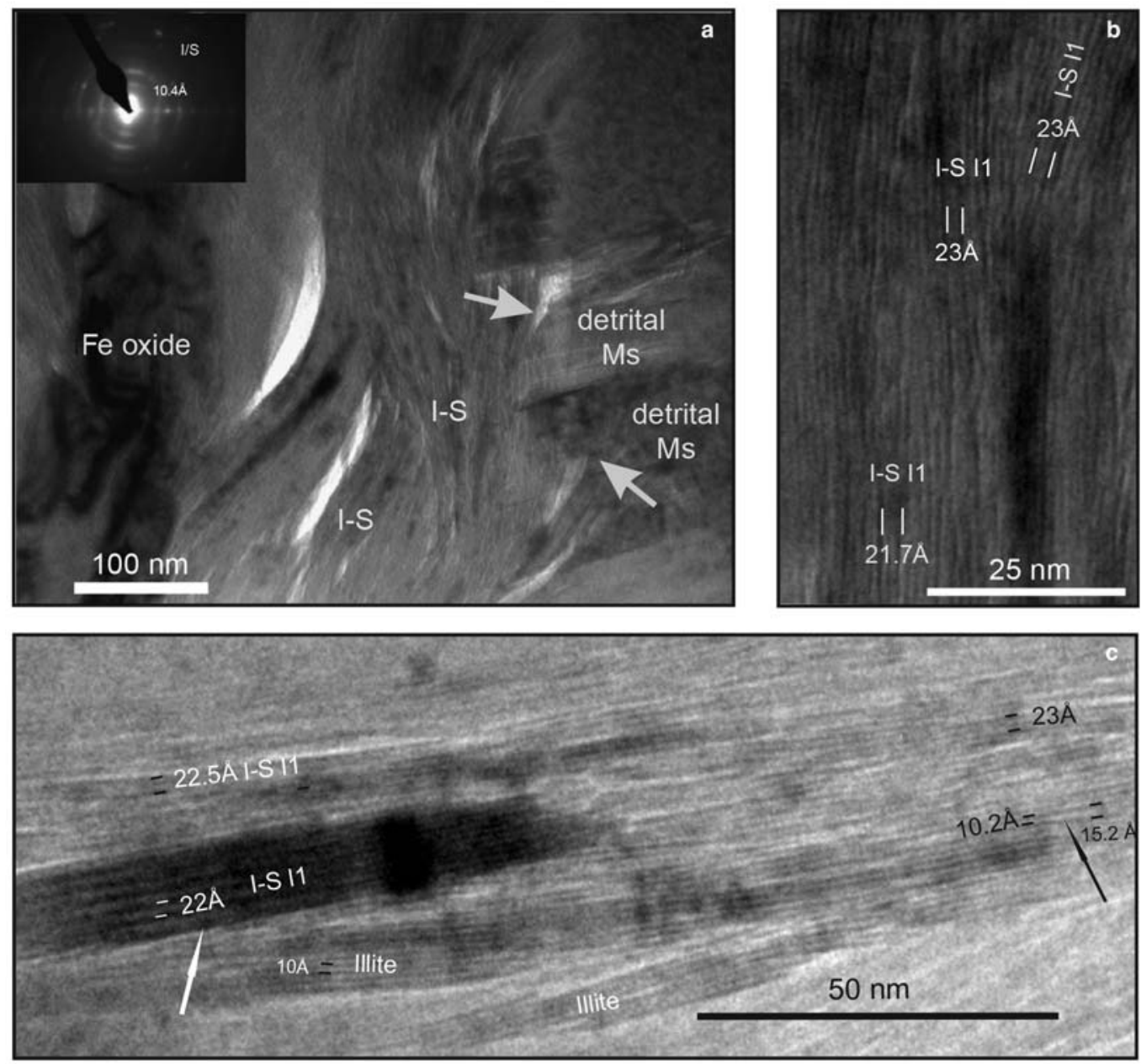

FIG. 7. TEM images of sample 1611-1. (a) Low-magnification lattice-fringe image: detrital micas curved and anastomosing packets of mixed-layer I-S oriented at high angles to the former; replacement of detrital micas by authigenic I-S can be seen (white arrows). Lens-shaped voids consistent with partial collapse caused by the TEM vacuum despite sample treatment with L.R. White resin and iron oxides in close association with authigenic I-S can be observed; inset: SAED pattern depicting very diffuse 10-10.4 $\AA$ (001) reflections elongated normal to $c^{*}$ as a result of curvature of I-S. (b) Lattice-fringe image of mixed-layer I-S packets; (001) fringes have a wavy appearance and spacings corresponding to the sum of illiteand smectite-like layer (21.7-23 A periodicity), low-angle boundaries between adjacent I-S mixed-layer packets can be seen. (c) Illite and mixed-layer I-S depicting low-angle boundaries between them (white arrow). Layer sequences corresponding to I1 ordering type (22.5-23 $\AA$ periodicity) including five consecutive I-S layers can be observed (lower left). An along-layer transition from 15.2 to $10.2 \AA$ can be seen (black arrow).

percentage of illite layers (determined by XRD) probably corresponding to the illite packets imaged by TEM. On the other hand, R0 I-S was not identified in the TEM images of the two shallowest samples, probably because it is very scarce, but also because more defective phases deteriorate easily in the vacuum of the ion mill and TEM. Accordingly, the type of mixed-layer I-S identified in
TEM images for each sample matches quite well with the results obtained by peak deconvolution using MacDiff, indicating that carefully interpreted good-quality XRD data may provide very useful information even in samples containing very complex phase assemblages.

Dong et al. (1997) demonstrated that the trends observed in XRD patterns are due to changes in the 

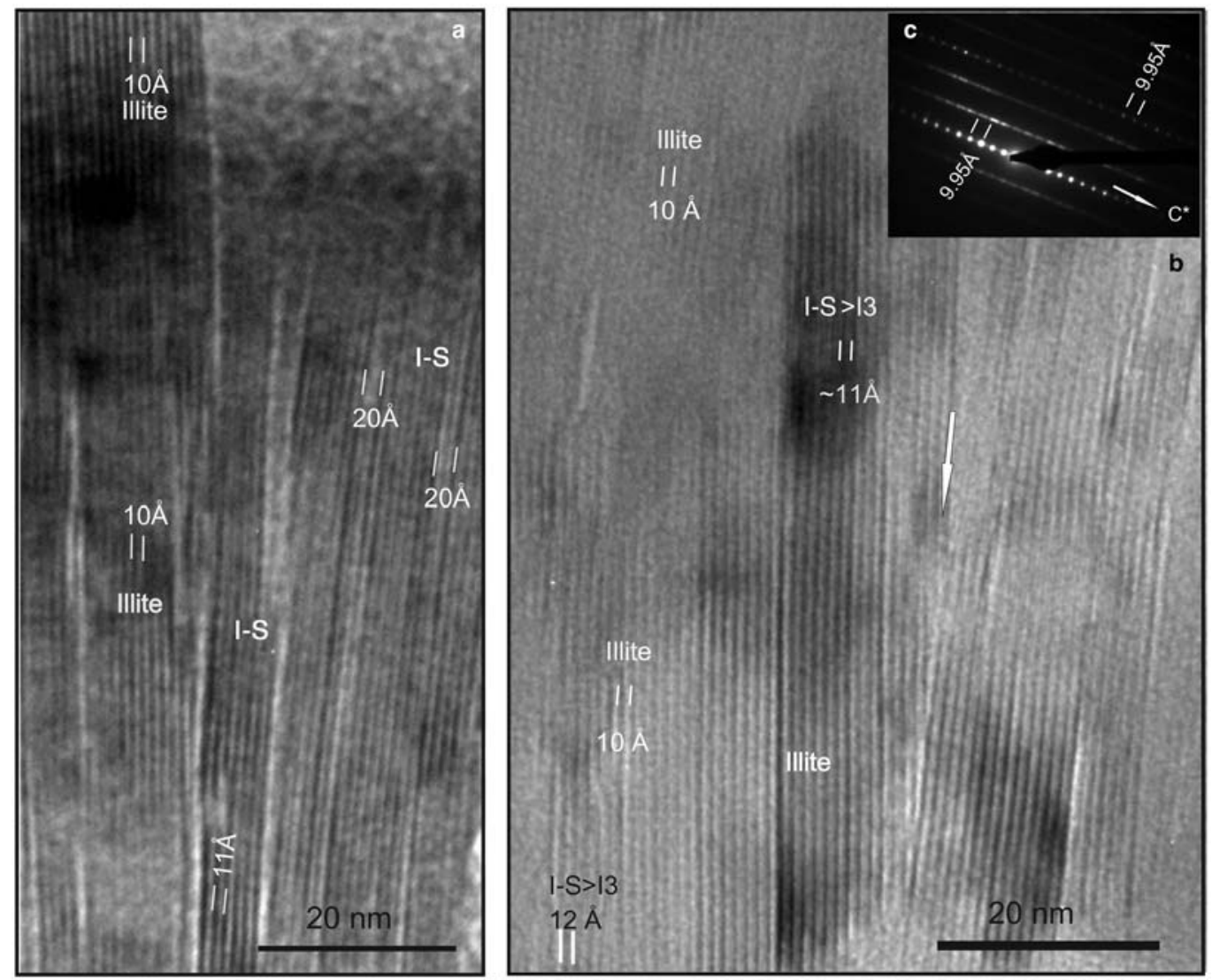

FIG. 8. Lattice-fringe images from the illite-rich areas of sample 5-7-08-1W (Maíz Gordo Formation). (a) Adjacent packets of illite and mixed-layer I-S corresponding to I $>3$ and I1 ordering type with low-angle boundaries between them; (b) Illite and mixed-layer I-S with I $>3$ ordering type; low-angle boundaries between adjacent packets can be seen (white arow). (c) SAED pattern of the illite crystals indicating $1 \mathrm{M}_{d}$ polytypism.

proportion of discrete phases and not in the proportion within sequences of layers of individual packets. In the present study, the discrete phases are I1 I-S, illite and probably smectite. R0 I-S was not identified, in agreement with all the previous images published in the diagenesis literature, and the minor presence of $\mathrm{R} \geq 3$, could represent residual layers of smectite not completely transformed during illitization.

\section{Chemical evolution of I-S with depth}

The chemical changes related to the diagenetic evolution of mixed-layer I-S have not yet been well constrained due to the intrinsic difficulty of analysing low-crystallinity phases, which at the same time have very small grain sizes and are difficult to separate from each other and from other minerals present in the sample. In addition, the coexistence in the same sample of various types of mixed-layer I-S (Arostegui et al., 2006; Sant'Anna et al., 2006; Ferrage et al., 2011) is another source of complication. To date, therefore, the respective fields of compositions of the various types of mixed-layer I-S have not been defined properly and a definitive criterion to classify smectite, illite and mixed-layer I-S phases, based on chemical composition only does not exist. Various authors have proposed that I-S chemistry does not need to reproduce exactly intermediate compositions between smectite and illite (Ahn \& Peacor, 1986; Jiang et al., 1990), in a similar way as was demonstrated for the equivalent smectite-chlorite series (Shau et al., 1990).

The structural formulae of Saladillo I-S (Table 1, Fig. 10) show the expected and previously described (Hower et al., 1976; Ahn \& Peacor, 1986) Si-for-Al 


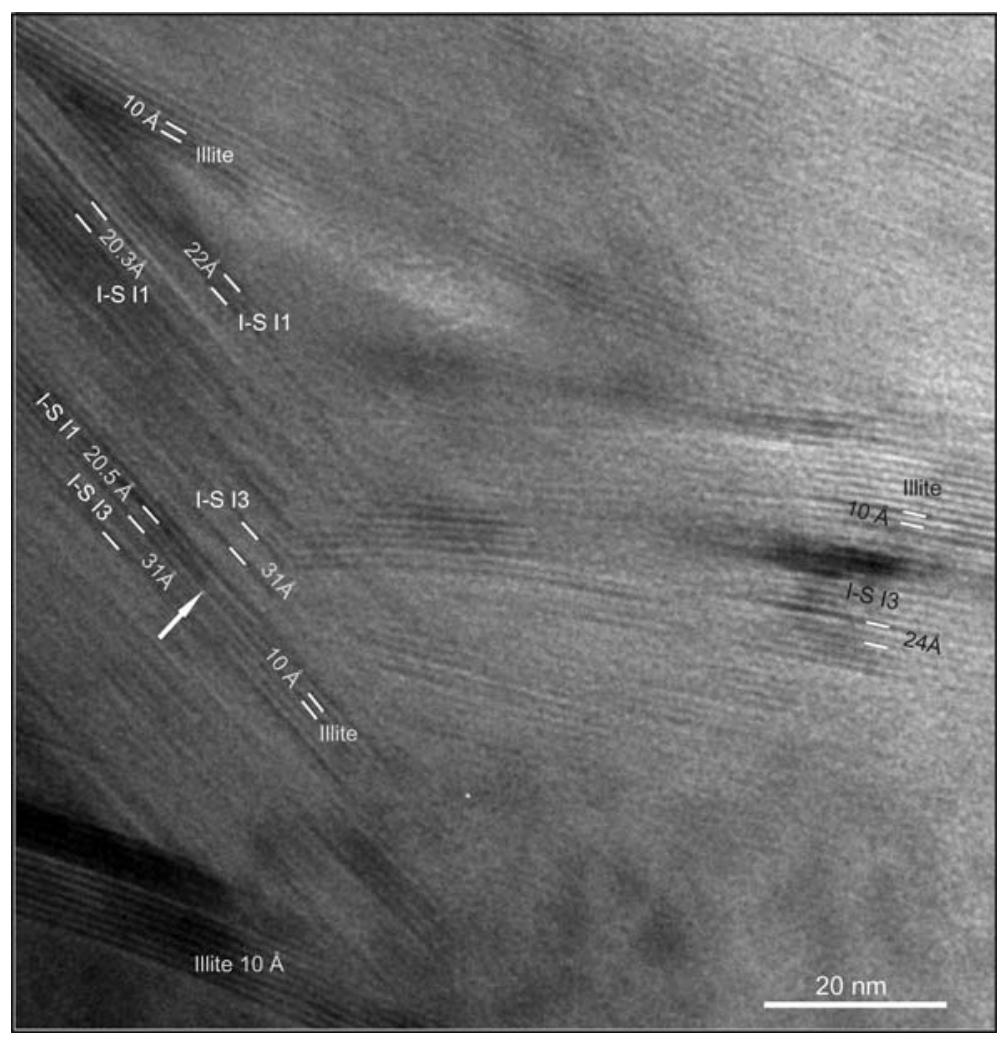

FIG. 9. Lattice-fringe image from a mixed-layer I-S-rich area of sample 5-7-08-1W (Maíz Gordo Formation). Packets of I-S, depicting layer sequences corresponding to I1 and I3 ordering type, and illite with no preferred orientation and highangle boundaries between them can be seen. An along-layer transition between I-S and illite is shown (white arrow)

substitution with depth. In terms of charge balance, this chemical change needs to be compensated by other changes producing a positive charge increase. This change is basically given by the $\mathrm{Mg}$ to $\mathrm{Al}$ substitution in the octahedral sheet (Fig. 10c). Therefore, the most significant change overall is the Tschermak substitution $\left[\left(\mathrm{Si}, \mathrm{Al}_{-1}\right)^{\mathrm{IV}},\left(\mathrm{Al}, \mathrm{Mg}_{-1}\right)^{\mathrm{VI}}\right]$, which is well known in other silicates, including metamorphic micas. The Tschermak component decreases to the bottom of the sequence, giving way to more muscovitic compositions.

The large compositional variation of mixed-layer I-S in the shallower samples is characteristic of metastable phases forming under low-temperature conditions. In contrast, the more homogenous composition of I-S in sample 5-7-8-1W (Fig. 10c) probably indicates higher temperatures and/or a higher fluid/rock ratio.

The change in Ca contents expected for a smectiteto-illite evolution has been employed successfully to differentiate the two end-member minerals and to obtain partial information about their mixed-layer phases
(Fig. 10b). Previous studies (e.g. Ahn \& Peacor, 1986; Drief \& Nieto, 2000) showed that the Ca contents in smectite or R0 I-S are not as high as assumed before the use of AEM. Therefore, even if the overall reduction of $\mathrm{Ca}$ is not substantial, the differences between shallower and the deepest, more evolved sample (Fig. 10b) are significant and confirm that the use of Ca contents as a differential criterion between smectite and illite in previous studies was justified.

To conclude, the traditionally accepted increase in tetrahedral charge due to the substitution of $\mathrm{Si}$ by $\mathrm{Al}$ is confirmed in the Saladillo samples, but the compositional vector able to explain such a change is not as simple as traditionally assumed. The overall chemical differences between smectite, the parent material, and the resultant illite are more complex than only the $\mathrm{Si} / \mathrm{Al}$ ratio and $\mathrm{K}$ content, because $\mathrm{Mg}$ and $\mathrm{Fe}$ also need to be less abundant, as they are abundant only in mediumhigh-pressure micas; $\mathrm{Ca}$ is a very minor component in micas and its substitution by a larger amount of $\mathrm{K}$ ions 
a

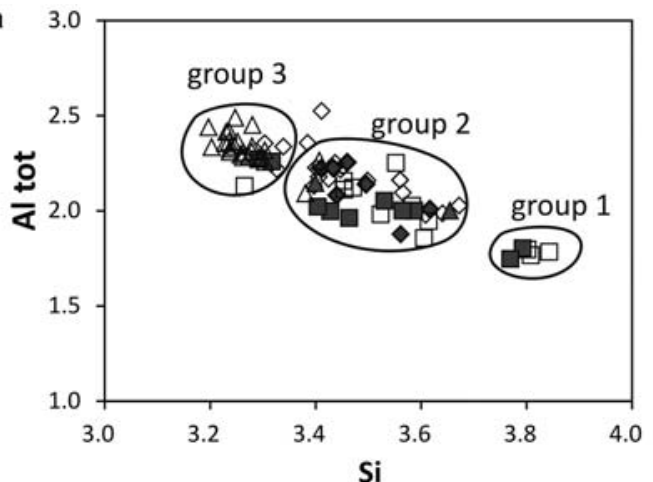

c

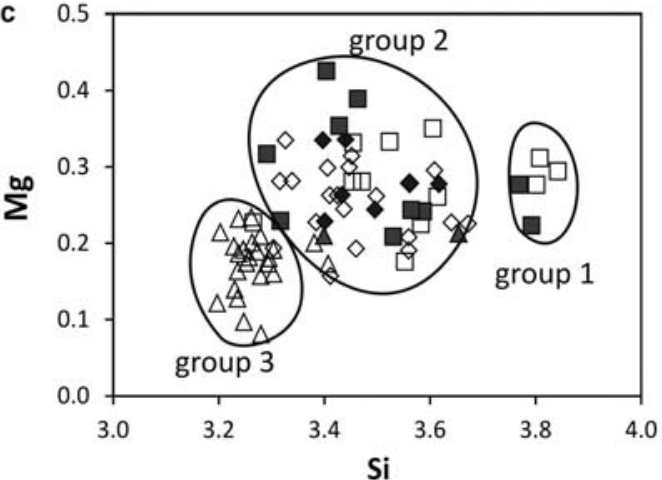

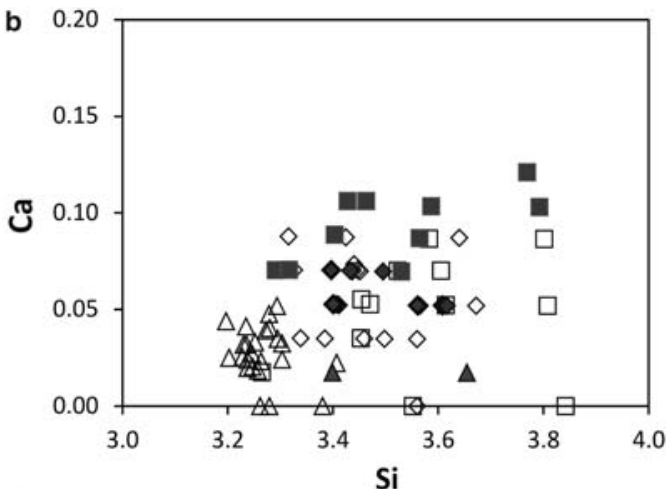

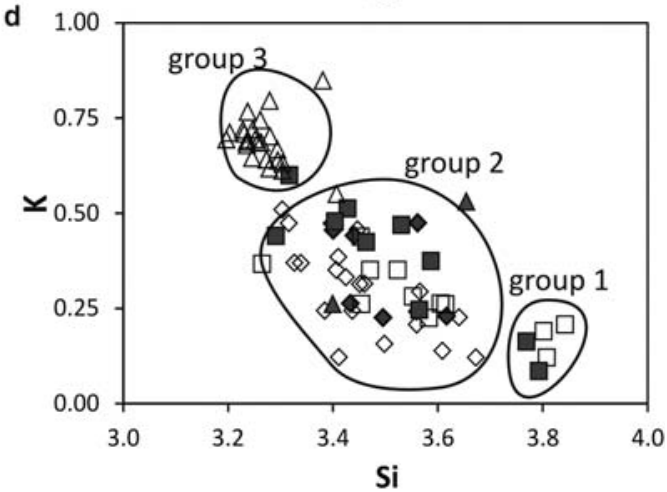

FIG. 10. Compositional plots for mixed-layer I-S phases. (a) Si-total Al graph; (b) Si-Ca graph; (c) Si-Mg graph; (d) Si-K graph. Rhombs: sample 411-4, squares: sample 1611-1 and triangles: sample 5-7-08-1W. Filled symbols correspond to data from Table 1 and open symbols to data from Do Campo et al. (2014).

in the interlayer (Fig. 10b,d) is less than necessary to compensate the significant increase in the tetrahedral charge. Therefore, together with the traditionally accepted reduction in the pyrophyllitic component, observable in the Saladillo samples (Fig. 10d), a decrease in Tschermak component (Fig. 10c) is also present in the illitization of smectite.

\section{Evolution and genesis of clays}

The evolution with depth in the dioctahedral clays inferred from XRD indicates a change in the diagenetic grade between samples 411-4 and 1611-1 on one hand and samples $5-7-08-6 \mathrm{~W}$ and $5-7-08-1 \mathrm{~W}$ on the other. The TEM images also support this trend, showing an increase in the illite $v s$. I1 I-S contents and in the thickness of authigenic illite crystals, and a decrease in the defects of illite crystals. In vast areas of the Los Colorados basin (including a control point $15 \mathrm{~km}$ south of Saladillo), these sequences were only affected by shallow diagenesis (Do Campo et al., 2007, 2010,
2014). Therefore, the diagenetic grade attained by the post-rift and the overlying foreland sediments in the northernmost Calchaquí Valley must be influenced by local factors. BSE images provide decisive evidence of dissolution of primary phases (K-feldspar, albite, white micas and quartz), and crystallization of secondary phyllosilicates, namely, illite, I-S and kaolinite. Textures evidencing dissolution-crystallization processes could be recognized in MG Formation and up to the middle levels of LCI sequence in QLC formation (Do Campo et al., 2014). As alteration of primary phases is not pervasive, an intermediate fluid/rock ratio might be inferred.

According to Do Campo et al. (2014), smectite would have been the common precursor of I-S mixedlayers in these sediments. In fact, smectite or R0 I-S are the dominant smectitic phases at the top of the sequence (Do Campo et al., 2014).

Remarkably, in the Saladillo section, beds containing dominant I1 mixed-layer I-S and those composed of illite or I3 mixed-layer I-S plus authigenic kaolinite 
are separated by $<250 \mathrm{~m}$ (Fig. 2b). Given the temperatures estimated for the transformation from R0 to R1 I-S in siliciclastic sediments of different basins $\left(75-120^{\circ} \mathrm{C}\right.$ ) (Hoffman \& Hower, 1979; Pollastro, 1993; Schegg \& Leu, 1996), and the transition temperature from R1 I-S to ordered R3 I-S in sediments older than $5 \mathrm{Ma}\left(\sim 175^{\circ} \mathrm{C}\right)$ (Pollastro, 1993), a geothermal gradient of $>220^{\circ} \mathrm{C} / \mathrm{km}$ would result, which is unrealistic for burial diagenesis. As mentioned above, considerable evidence indicates that the formation of illite, I3 mixedlayer I-S, plus kaolinite in the Paleogene continental sediments at the Saladillo site is exceptional, and was not controlled by burial temperature alone.

The textures observed in TEM images (Fig. 7a) strongly suggest that illitization mainly proceeded by dissolution-crystallization: (1) packets exhibit a curved and anastomosing morphology, without preferential orientation, and (2) packets with frayed borders display high-angle layer terminations with adjacent packets (Fig. 7a). However, few examples were found of layerby-layer replacement among the tens of images obtained (Fig. 6c). According to Altaner \& Ylagan (1997), the fluid/rock ratio and permeability influence the reaction mechanisms of smectite illitization, with high fluid/rock ratios favouring dissolution-crystallization processes. In the same way, the fan-like texture depicted by authigenic kaolinite is indicative of precipitation from a fluid phase. It is in agreement with the evidence of dissolution and crystallization of kaolinite, mixed-layer I-S and illite observed at SEM scale.

The wide range of compositional variation depicted by the mixed-layer I-S studied is characteristic of metastable phases formed under low-temperature conditions, which follow the 'Ostwald Step Rule'. The composition of each individual grain is a consequence not only of temperature and pressure conditions, but also of the parent material and chemical environment at the micrometre scale. Another indicator of thermodynamic disequilibrium is the coexistence of I-S with different Reicheweite values and illite in a single sample at a distance of around $50 \mathrm{~nm}$ (Fig. 9). The faults that bound the northern Calchaquí Valley (Toro Muerto and Calchaquí reverse faults) are only $4 \mathrm{~km}$ apart in the Saladillo area, whereas the sampling points are $<1 \mathrm{~km}$ from the fault planes. Syndepositional deformation features preserved in the Paleogene sediments of the study area, the Neogene refolding of the Eocene folds, the link with Quaternary volcanic centres, and historical earthquakes (Marrett et al., 1994; Hongn et al., 2007) corroborate the fact that these faults were active at several stages during the Cenozoic. In fact, the faults may have facilitated the circulation of hot deep fluids that increased the fluid/rock ratios and enhanced heat transport, thus favouring the illitization of smectite by dissolution-crystallization processes. Furthermore, permeable sandstone and conglomerate sandstone layers interbedded with claystone and siltstone levels may have facilitated fluid flow near the faults. Stress might also have contributed to the attainment of deep diagenesis at the illite (or I3 mixed-layer I-S) stage in these young continental sediments.

The connection between areas showing advanced reaction progress in I-S evolution and the activity of fluids in faulted zones has been mentioned previously for different basins (Uysal et al., 2000; Abid \& Hesse, 2007; Abad et al., 2010, 2012; Middleton et al., 2015). In several cases, the authors could not conclude with certainty whether fluids were involved directly in smectite illitization or if they only acted as heat carriers (Uysal et al., 2000). On the other hand, Abid \& Hesse (2007) concluded that fluids channeled by faults were involved directly in diagenetic reactions yielding anomalous areas of enhanced illitization in the offshore Jeanne d'Arc Basin of Canada. Likewise, Middleton et al. (2015) described several generations of illite $(\mathrm{R} \geq 3)$ precipitation from Merrimelia-Innamincka Ridge (Warburton-Cooper basins, central Australia) sediments associated with the reactivation of fracture networks that would have acted as highly permeable conduits for hydrothermal fluid flow during the Carboniferous and Late Triassic tectonothermal events. Middleton et al. (2015) suggested that the precipitation of authigenic clays in these sediments proceed from alteration of detrital feldspars and micas during the repeated periods of fault activity and fluid flow which brought high water/rock ratios and a led to a high palaeogeothermal gradient $\left(\sim 100^{\circ} \mathrm{C} \mathrm{km}^{-1}\right)$.

\section{ACKNOWLEDGEMENTS}

The help of M.M. Abad-Ortega (Centro de Instrumentación Cientifica, University of Granada) with the TEM and AEM, Maria Angeles Laguna with TEM and Cristina Gallego with FESEM (University of Zaragoza) was essential for the present work. The authors wish to acknowledge the use of the Servicio General de Apoyo a la Investigación-SAI, University of Zaragoza, Spain. The authors are grateful to C. Brime and an anonymous reviewer for their valuable and constructive comments. This work was financed in part by the grants CONICET-PIP 489 and ANCyT-PICT 0407, Research Projects CGL2011-30153-C02-01 and CGL201346169-C2-1-P (Spanish Ministry of Science), and the Gobierno de Aragón and the European Social Fund 
(Grupos Consolidados). The stay of M. Do Campo at the University of Granada and the field work of Fernando Nieto in Argentina were supported by AECI project A/7712/07.

\section{REFERENCES}

Abad I., Murphy B.J., Nieto F. \& Gutiérrez-Alonso G. (2010) Diagenesis to metamorphism transition in an episutural basin: the late Paleozoic St. Mary's Basin, Nova Scotia, Canada. Canadian Journal of Earth Sciences, 47, 121-135.

Abad I., Nieto F., Gutiérrez-Alonso G., Murphy B.J., Braid J.A. \& Rodríguez-Navarro A.B. (2012) Fluiddriven low-grade metamorphism in polydeformed rocks of Avalonia (Arisaig Group, Nova Scotia, Canada). Swiss Journal of Geosciences, 105, 283-297.

Abid I.A. \& Hesse R. (2007) Illitizing fluids as precursors of hydrocarbon migration along transfer and boundary faults of the Jeanne d'Arc Basin offshore Newfoundland, Canada. Marine and Petroleum Geology, 24, 237-245.

Abid I.A., Hesse R. \& Harper J.D. (2004) Variations in mixed-layer illite/smectite diagenesis in the rift and post-rift sediments of the Jeanne d'Arc Basin, Grand Banks offshore Newfoundland, Canada. Canadian Journal of Earth Sciences, 41, 401-429.

Ahn J.H. \& Peacor D.R. (1986) Transmission and analytical electron microscopy of the smectite-to-llite transition. Clays and Clay Minerals, 34, 165-179.

Ahn J.H. \& Peacor D.R. (1989) Illite/smectite from Gulf Coast: A reappraisal of the transmission electron microscopy images. Clays and Clay Minerals, 37, 542-546.

Allen P.A. \& Allen J.R. (2005) Basin Analysis. Principles and Applications. Second edition, Blackwell Publishing, Oxford, UK, 549 pp.

Altaner S.P. \& Ylagan R.F. (1997) Comparison of structural models of mixed-layer illite/smectite and reaction mechanisms of smectite illitization. Clays and Clay Minerals, 45, 517-533.

Altaner S.P., Whitney G., Aronson J.L. \& Hower J. (1984) A model for K-bentonite formation, evidence from zoned K-bentonites in the disturbed bed of Montana. Geology, 12, 412-415.

Arostegui J., Irabien M.J. \& Nieto F. (2001) Microtextures and the origin of muscovite-kaolinite intergrowths in sandstones of the Utrillas Formation, Basque Cantabrian Basin, Spain. Clays and Clay Minerals, 49, 529-539.

Arostegui J., Sangüesa F.J., Nieto F. \& Uriarte J.A. (2006) Thermal models and clay diagenesis in the TertiaryCretaceous sediments of the Alava block (BasqueCantabrian basin, Spain). Clay Minerals, 41, 791-809.

Bauluz B., Peacor D.R. \& González López J.M. (2000) Transmission electron microscopy study of illitization in pelites from the Iberian Range, Spain, layer-by-layer replacement? Clays and Clay Minerals, 48, 374-384.
Cuadros J. (2006) Modeling of smectite illitization in burial diagenesis environments. Geochimica et Cosmochimica Acta, 70, 4181-4195.

De Ros L.F. (1998) Heterogeneous generation and evolution of diagenetic quartzarenites in the SilurianDevonian Fumas Formation of the Paran Basin, southern Brazil. Sedimentary Geology, 116, 99-128.

del Papa C., Hongn F., Petrinovic I. \& Domínguez R. (2004) Evidencias de deformación pre-miocena media asociada al antepaís andino en la Cordillera Oriental (243'은 $\left.66^{\circ} 12^{\prime} \mathrm{O}\right)$. Asociación Geológica Argentina, Revista, 59, 506-509.

del Papa C., Hongn F., Powell J., Payrola P., Do Campo M., Strecker M.P., Petrinovic I., Schmitt A. \& Pereyra R. (2013) Middle Eocene-Oligocene broken foreland evolution in the Andean Calchaqui Valley, NW Argentina: insights from stratigraphic, structural, and provenance studies. Basin Research, 25, 574-593.

Díaz J.I. \& Malizzia D.C. (1983) Estudio geológico y sedimentológico del Terciario superior del Valle Calchaquí (Departamento de San Carlos, Prov. De Salta). Boletín Sedimentológico, 2, 8-28.

Do Campo M., del Papa C., Jiménez-Millán J. \& Nieto F. (2007) Clay mineral assemblages and analcime formation in a Paleogene fluvial-lacustrine sequence (Maiz Gordo Formation) from Northwestern Argentina. Sedimentary Geology, 201, 56-74.

Do Campo M., del Papa C., Nieto F., Hongn F. \& Petrinovic I. (2010) Integrated analysis for constraining palaeoclimatic and volcanic influences on claymineral assemblages in orogenic basins (Paleogene Andean foreland, Northwestern Argentina). Sedimentary Geology, 228, 98-112.

Do Campo M., Nieto F., del Papa C. \& Hongn F. (2014) Syn- and post-sedimentary controls on clay minerals assemblages in a tectonically active basin, Andean Argentinean Foreland. Journal of South American Earth Sciences, 52: 43-56.

Dong H. \& Peacor D.R. (1996) TEM observations of coherent stacking relations in smectite, I-S and illite of shales: evidence for McEwan relations in crystallites and dominance of 2M1 polytypism. Clays and Clay Minerals, 44, 257-275.

Dong H., Peacor D.R. \& Freed R.L. (1997) Phase relations among smectite, R1 illite-smectite, and illite. American Mineralogist, 82, 379-391.

Dorsey R.J., Buchovencky E.J. \& Lundberg N. (1988) Clay mineralogy of Pliocene-Pleistocene mudstones, eastern Taiwan: Combined effects of burial diagenesis and provenance unroofing. Geology, 16, 944-947.

Drief A. \& Nieto F. (2000) Chemical composition of smectites formed in clastic sediments. Implications for the smectite-illite transformation. Clay Minerals, 35, $665-678$.

Ferrage E., Vidal O., Mosser-Ruck R., Cathelineau M. \& Cuadros J. (2011) A reinvestigation of smectite illitization in experimental hydrothermal conditions: 
Results from X-ray diffraction and transmission electron microscopy. American Mineralogist, 96, 207-223.

Guzmán S. \& Petrinovic I. (2008) Pucarilla-Cerro Tipillas Volcanic Complex: the oldest recognized caldera in the southeastern portion of Central Volcanic Zone of Central Andes? Collapse Calderas Workshop IOP Conference Series. Earth and Environmental Science, 3, 012003. IOP Publishing. doi:10.1088/1755-1307/3/ $1 / 012003$.

Hoffman J. \& Hower J. (1979) Clay mineral assemblages as low grade metamorphic geothermometers: Application to the thrust faulted Disturbed Belt of Montana, U. S. A. Pp. 55-79 in: Aspect of Diagenesis (P.A. Scholle \& P.S. Schluger, editors). Special Publication 26, Society of Economic Paleontologists and Mineralogists, Tulsa, Oklahoma, USA.

Hongn F., del Papa C.E., Powell J., Petrinovic I.A., Mon R. \& Deraco V. (2007) Middle Eocene deformation and sedimentation in the Puna-Eastern Cordillera transition $\left(23^{\circ}-26^{\circ} \mathrm{S}\right)$ : Control by preexisting heterogeneities on the pattern of initial Andean shortening. Geology, 35, 271-274.

Hower J., Eslinger E.V., Hower M.E. \& Perry E.A. (1976) Mechanism of burial metamorphism of argillaceous sediments: Mineralogical and chemical evidence. Geological Society of America Bulletin, 87, 725-737.

Huang W.-L., Longo J.M. \& Pevear D.R. (1993) An experimentally derived kinetic model for smectite-toillite conversion and its use as a geothermometer. Clays and Clay Minerals, 41, 162-177.

Jiang W.-T., Peacor D.R., Merriman R.J. \& Roberts B. (1990) Transmission and analytical electron microscopic study of mixed-layer illite-smectite formed as an apparent replacement product of diagenetic illite. Clays and Clay Minerals, 38, 449-468.

Kim J.W., Peacor D.R., Tessier D. \& Elsass F. (1995) A technique for maintaining texture and permanent expansion of smectite interlayers for TEM observations. Clays and Clay Minerals, 43, 51-57.

Marquillas R., del Papa C. \& Sabino I. (2005) Sedimentary aspects and paleo-environmental evolution of a rift basin: Salta Group (CretaceousPaleogene), northwestern Argentina. International Journal of Earth Sciences, 94, 94-113.

Marrett R.A., Allmendiger R.W., Alonso R.N. \& Drake R. E. (1994) Late Cenozoic tectonic evolution of the Puna plateau and adjacent foreland, northwestern Argentine Andes. Journal of South American Earth Science, 7, 179-208.

Middleton A.W., Tonguc I. Uysal S. \& Golding D. (2015) Chemical and mineralogical characterisation of illitesmectite: Implications for episodic tectonism and associated fluid flow, central Australia. Geochimica et Cosmochimica Acta, 148, 284-303.

Moore D.M. \& Reynolds R.C. (1997) X-ray Diffraction and the Identification and Analysis of Clay Minerals. Oxford University Press, Oxford, UK.
Nieto F., Ortega-Huertas M., Peacor D.R. \& Arostegui J. (1996) Evolution of illite/smectite from shallow diagenesis through incipient metamorphism in sediments of the Basque-Cantabrian Basin. Clays and Clay Minerals, 44, 304-323.

Petschick R. (2004) http://www.geol-pal.uni-frankfurt.de/ Staff/Homepages/Petschick/classicsoftware.html\# MacDiff.

Pollastro R.M. (1993) Considerations and applications of the illite/smectite geothermometer in hydrocarbonbearing rocks of Miocene to Mississippian age. Clays and Clay Minerals, 41, 119-133.

Salfity J.A. \& Marquillas R.A. (1994) Tectonic and sedimentary evolution of the Cretaceous-Eocene Salta Group Basin, Argentina. Pp. 266-315 in: Cretaceous Tectonics of the Andes (J.A. Salfity, editor). Earth Evolution Sciences Monograph Series, Friedrich Vieweg \& Sohn, Braunschweig/ Wiesbaden, Germany.

Sant'Anna L.G., Clauer N., Cordani U.G., Riccomini C., Velázquez V.F. \& Liewig N. (2006) Origin and migration timing of hydrothermal fluids in sedimentary rocks of the Paraná Basin, South America. Chemical Geology, 230, 1-21.

Schegg R. \& Leu W. (1996) Clay mineral diagenesis and thermal history of the Thonex Well, Western Swiss Molasse Basin. Clays and Clay Minerals, 44, 693-705.

Shau Y.-H., Peacor D.R. \& Essene E.J. (1990) Corrensite and mixed-layer chlorite/corrensite in metabasalt from northern Taiwan: TEM, AEM, EMPA, XRD and optical studies. Contributions to Mineralogy and Petrology, 105, 123-142.

Turner J.C. (1959) Estratigrafía del cordón de Escaya y de la sierra de Rinconada (Jujuy). Revista de la Asociación Geológica Argentina, 13, 15-39.

Turner J.C.M. (1960) Estratigrafía de la Sierra de Santa Victoria y adyacencias. Boletín Academia Nacional de Ciencias de Cordoba, 41, 163-196.

Uysal I.T., Glikson M., Golding S.D. \& Audsley F. (2000) The thermal history of the Bowen Basin, Queensland, Australia: Vitrinite reflectance and clay mineralogy of Late Permian coal measures. Tectonophysics, 323, 105-129.

Veblen D.R., Guthrie Jr, G.D., Livi K.J.T. \& Reynolds R.C. Jr. (1990) High-resolution transmission electron microscopy and electron diffraction of mixed-layer illite/smectite: Experimental results. Clays and Clays Minerals, 38, 1-13.

Whitney G. (1990) Role of water in the smectite-to-illite reaction. Clays and Clay Minerals, 38, 343-350.

Whitney G. \& Northrop H.R. (1988) Experimental investigation of the smectite to illite reaction: Dual reaction mechanisms and oxygen-isotope systematics. American Mineralogist, 73, 77-90.

Whitney D.L. \& Evans B.W. (2010) Abbreviations for names of rock-forming minerals. American Mineralogist, 95, 185-187. 